\title{
Study of qualitative characteristics of burgers from beef partially replaced by truffle during different storage periods
}

\author{
Gaidda Ali Makkia , Esraa Yacoob Yousifa \\ ${ }^{a}$ Animal Production Department-Agriculture College-Basrah University Basrah, Iraq.
}

ABSTRACT The current study aimed at the possibility of substituting truffles instead of beef in the beef patties at rates of $0,20,40$ and $60 \%$ for different storage periods $(0,15,30$ and 60 days in freezing at a temperature of $-18{ }^{\circ} \mathrm{C}$ ) and to study the qualitative and microbial characteristics. $40 \%$ showed a significant difference in all the studied traits and a decrease in the indicators of oxidation and rancidity, as was observed a significant reductionin the peroxide values and the free fatty acids percentage of the meat samples treated with plant extracts compared to the control treatment which amounted to 4.51 $\mathrm{mm}$ caffeine/ $\mathrm{kg}$ of fat and $1.15 \%$ respectively on day 60 of preservation as treated samples remained within standard limits. The replacement samples also showed a significant decrease in the total number of cold-loving bacteria and bacteria compared to the control treatment during the different storage periods.

KEYWORDS: fatty acids; microbial characteristics; nutritional health; oxidation.

Accepted February 2, 2021 Published online April 8, 2021

Cite this article: Makki and Yousif (2021) Study of qualitative characteristics of burgers from beef partially replaced by truffle during different storage periods. Multidisciplinary Science Journal 3: e2021007, doi: 10.29327/multiscience.2021007.

\section{Introduction}

In the recent era, the world is witnessing nutritional health risks resulting from several causes, including high blood pressure, a higher incidence of cardiovascular disease, blood vessel problems, and cholesterol, which are some causes of eating meat. As studies have indicated, vegetarians are less affected by these diseases compared to people who eat meat regularly, as well as the low mortality rate when vegetarians (Al-Hamili 2005; Kotwaliwale et al 2007; Chye et al 2008).

Because of the population growth, the world is witnessing at present a decrease in the red meat produced, which are considered the most important food sources in human nutrition because it contains a high percentage of proteins, fats, iron, and phosphorous. Studies began with the use of methods for processing meat using meat substitutes of all kinds with plant sources to improve the quality, and sensory characteristics of processed meat, especially the beef patties industry on the one hand and reduce the cost of production on the other hand, through the use of nutritional alternatives that have lower costs and have no adverse effects on human health (Al-Aswad 20019).

Plant proteins have been used as a molecular substitute in the manufacture of various types, as the cost of animal protein is associated with a lower percentage of fat and cholesterol (Dunkwal 2007). That the truffle mushroom (Terfeziaceae) does not belong to the botanical world in the correct sense because it is devoid of chlorophyll. It is unique in its nature and composition. It does not contain dangerous elements, as it contains water in a high proportion and does not share the type of dietary fiber with the plant, but the truffle does not contain cellulose or wood, but it contains chitin. This dietary fiber type is not found in the plant (Morte et al 2008; Martins and Ferreira 2010).

The truffle grows in the form of a tuber of underground potatoes and can be found by tracking the ground's crack above it or by its presence near the plum plant types of desert plants such as oak trees (Gutièrrez et al 2003). One of the benefits of appeared is reducing the possibility of developing malignant tumors thanks to its richness in antioxidants, which contribute to resistance to free radicals and prevent toxins from entering cells, reducing harmful cholesterol in 
the blood, thanks to the fact that it contains plant fibers (Akyuz 2013). It protects the individual from atherosclerosis and subsequent coronary artery disease, high blood pressure, angina pectoris, and heart attacks. It supplies the body with energy and vitality, which helps to soften the arteries and joints, thanks to their containment of unsaturated fatty acids, improving the body's immune system increases the ability to repel foreign bodies, whether viral, bacterial, or bacterial. Also, improving the functioning of the nervous system in the body thanks to its containment of vitamin B compounds such as thiamine, riboflavin, pyridoxine, and cyanocobalamin (Morte et al 2008).

Truffles also contain copper, which makes them among the harmful cholesterol-lowering substances. Copper is the mineral that converts metallic iron into hemoglobin iron and stimulates red cell growth to protect the body from severe anemia. Copper is not present in many materials in sufficient quantity, and it is also one of the minerals that are absorbed in the morning (Gutièrrez et al 2003; Pereira et al 2012). In addition to the basic mineral salts, truffles contain vitamins from the vitamin B group, including vitamins B1 or thiamin and vitamins B2 or riboflavin. The truffles also contain niacin or vitamin B3 and folic acid (Akyuz 2013). Truffles are classified as protein-rich substances since they contain high-quality protein due to their richness in the essential amino acid (Aldebasi 2013), in addition to their abundance in Iraq and their low prices in the local markets.

Therefore, the study aimed at a partial replacement of meat with quanta and to study the qualitative and sensory characteristics of baker discs made from beef.

\section{Material and Methods}

\section{The mushroom}

It was purchased from the Basra governorate market to study its antioxidant and antibacterial effects.

\section{The meat}

The beef veal (thigh area) was obtained from the local markets of Basra Governorate in the early morning. It was placed in refrigerated containers and sterilized directly. The animal's age was from 1.5-2 years after removing the outer layer of fat that covered the piece of meat. The meat was kept in the refrigerator at a temperature 4 으 $\mathrm{C}$ after chopping until use and for different periods.

\section{Spices, garlic, and salt}

It was obtained from the markets of Basra Governorate. The process of manufacturing and processing meat tablets. The meat was minced after conducting the physical inventory and removing the fat, and the meat was added according to the experiment parameters as follows:

1 -The first treatment without adding the extracts as a control group (0\%).

2 -The second transaction (20\%) replacement.

3 -Third transaction replacement (40\%).

4 -Fourth treatment replacement (60\%).

The beef patties were made with a weight of 100 grams per tablet, and they were refrigerated at a temperature of $4{ }^{\circ} \mathrm{C}$. Measurements were taken every $(0,15,30$, and 60 days), and chemical and microbiological tests were performed for the meat during the different preservation period.

\section{Chemical tests}

\section{Peroxide number}

The peroxide number was estimated according to the Pearson method (1981), according to the following equation 1:

$$
\text { (1) Peroxide value }=\frac{\left(\mathrm{Na}_{2} \mathrm{~S}_{3} \mathrm{O}_{4} \mathrm{ml} \times \mathrm{N} \times 1000\right)}{(\text { Wt of Sample, gm })}
$$

Free Fatty Acids 
Estimated Free Fatty Acids (FFA) based on the Pearson et al. (1981) according to the following equation 2:

(2) Free Fatty Acid \% $=\frac{\text { Titration }(\mathrm{A}-\mathrm{B}) \times \mathrm{N} \times 282 \times 100}{1000 \times \mathrm{Wt} \text { of Sample, gm }}$

$\mathrm{A}=$ number of milliliters of $\mathrm{KOH}$ swabbed with a sample of fat or oil.

$\mathrm{B}=$ the number of $\mathrm{KOH}$ milliliters scanned with the Planck sample $=282$ molecular oleic acid weight.

\section{Cholesterol concentration}

The concentration of cholesterol in the meat samples was estimated according to the Al-Obaidi method (1999) modified by Al-Salhi (2012). I took a piece of meat, chopped and mixed it well, and took $0.1 \mathrm{~g}$ of this mixture, added 1.9 $\mathrm{ml}$ of ethanol alcohol to it, and shaken the solution well. It was centrifuged at $3000 \mathrm{rpm}$ for 15 minutes. After that, 0.25 $\mathrm{ml}$ of ferric chloride solution, which was prepared by dissolving $0.1 \mathrm{~g}$ of non-liquefied ferric chloride, was added to 100 $\mathrm{ml}$ of ethyl acetate, then $2 \mathrm{ml}$ of concentrated sulfuric acid into the form and shake well and leave until it cools and read the optical absorption at a wavelength of $560 \mathrm{~nm}$.

According to what was stated in the kit instructions prepared by the French company Biolabs SA, the standard cholesterol concentration was measured. It was prepared by adding $1 \mathrm{ml}$ of reagent solution, and $10 \mu \mathrm{l}$ of Standard solution was added to it and incubated for five minutes in the water bath at a temperature of $37^{\circ} \mathrm{C}$. Read the optical absorption on The wavelength of $500 \mathrm{~nm}$ in a spectrophotometer and extract the cholesterol concentration of the meat by applying the following equation 3 :

(3) Cholesterol concentration $(\mathrm{mg} / \mathrm{g})=$ (sample read) / (standard cholesterol reading) $\times 2$

\section{Microbiological tests}

Bacteriological tests were performed on meat samples that included total bacterial count (TPC) and numbers of psychrophilic bacteria.

\section{Statistical analysis}

The results were analyzed statistically using a three-factor factor trial with Complete Randomized Design (CRD). The data were statistically analyzed using the ready-made statistical program SPSS (SPSS, 2006). The results were compared using the lowest significant difference rate (R.L.S.D.) at a probability level of 0.05 .

\section{Results and discussion}

\section{Peroxide number}

The results of Table (1) show a significant decrease in the peroxide number values for the treated meat tablets with different concentrations of quantities compared to the control sample. On the fifteenth day, the average was 3.383 $\mathrm{mEq}$ in the control sample and decreased significantly to 2.32, 2.29, and $2.33 \mathrm{mEq} / \mathrm{g}$. Using 20, 40, and 60\% of Birker, the amount was added to different concentrations, respectively. The results also showed an increase in the value of the peroxide number in the control sample at day 60 of freezing at a temperature of $-18{ }^{\circ} \mathrm{C}$, as the average was $4.51 \mathrm{mEq} / \mathrm{g}$. The limits exceeded the standard specification, while the partially substituted samples of the quantities kept the averages of the peroxide number within the standard limits until the 60th day of freezing, as the averages were 2.64, 2.50 , and $2.48 \mathrm{mEq} / \mathrm{g}$, respectively. The value of peroxide is an essential indicator for measuring fat rancidity and oxidation, which results in free radicals causing deterioration in the flavor of meat (Khan et al 2009). The study agreed with Ferreira et al (2009) when studying the antioxidant effect of wild mushrooms.

Table 1 The effect of partial replacement of the quantities in the values of the peroxide number of beef tablets made from beef.

\begin{tabular}{cccccc}
\hline Concentration (mEq/g) & \multicolumn{4}{c}{ Period (day) } & \multicolumn{2}{c}{ Mean (ml) } \\
\cline { 3 - 4 } & 0 & 15 & 30 & 60 & \\
\hline 0 & 2.310 & 3.383 & 3.383 & 4.517 & 3.515 \\
20 & 2.310 & 2.327 & 2.327 & 2.640 & 2.459 \\
40 & 2.310 & 2.297 & 2.297 & 2.503 & 2.374 \\
60 & 2.310 & 2.333 & 2.333 & 2.480 & 2.374 \\
Mean & 2.310 & 2.585 & 2.793 & 3.035 & SEM 0.0578 \\
\hline & 0.2356 & & & & RLSD \\
& 0.1157 & & & & SEM Intraction \\
\hline
\end{tabular}




\section{Free fatty acid percentage}

The results of Table 2 show a significant decrease $(p<0.05)$ in the percentage of free fatty acids in Birker meat partially substituted with bulk compared to the control sample with increasing periods of preservation by freezing. It was noticed that the average percentage of FFA in the control sample exceeded the limits of the standard at the end of the second month, as the average percentage of free fatty acids in it was (1.15\%), while the average percentage of free fatty acids in the discs of meat partially substituted with quantities $0.77,0.70$ and $0.48 \%$, respectively, and thus it would have kept it within the permissible limits.

As the partial replacement of the quantities led to a delay of the lytic rinse, and the reason for this is that it is a source of chemical compounds with the ability to reduce microbial growth, such as phenolic compounds and flavonoids(Morte et al 2008). Thus it limits the growth of bacteria secreted by the enzyme lipase, which works on the occurrence of lytic osmosis (Al-Laith 2010). The results of Table 2 also showed the superiority of the fourth treatment, with a concentration of $60 \%$, in reducing the value of FFA and for all storage periods.

Table 2 The effect of partial substitution of the amount of free fatty acids on beef tablets made from beef.

\begin{tabular}{|c|c|c|c|c|c|}
\hline \multirow[t]{2}{*}{ Concentration (\%) } & \multirow[b]{2}{*}{0} & \multicolumn{2}{|c|}{ Periods (day) } & \multirow[b]{2}{*}{60} & \multirow[t]{2}{*}{ Mean (ml) } \\
\hline & & 15 & 30 & & \\
\hline 0 & 0.3400 & 0.6633 & 0.9767 & 1.1533 & 0.7833 \\
\hline 20 & 0.3400 & 0.3700 & 0.5933 & 0.7767 & 0.5200 \\
\hline 40 & 0.3400 & 0.4133 & 0.5133 & 0.7000 & 0.4917 \\
\hline 60 & 0.3400 & 0.4267 & 0.6350 & 0.4833 & 0.4266 \\
\hline Mean & 0.3400 & 0.4683 & 0.6350 & 0.7783 & \\
\hline \multicolumn{5}{|c|}{0.05064} & RLSD \\
\hline \multicolumn{5}{|c|}{0.02486} & SEM interaction \\
\hline
\end{tabular}

\section{Cholesterol}

The results of Table 3 showed the values of cholesterol concentrations for tablets of frozen beef, and there was a significant effect $(p<0.05)$ in the concentration of cholesterol among samples of meat partially substituted with quantities at concentrations $0,20,40$, and $60 \%$. One month of preservation period by freezing at $-18^{\circ} \mathrm{C}$, a significant decrease in the cholesterol concentration $(1.61,1.31$, and 1.42$) \mathrm{mg} / \mathrm{g}$ meat, respectively, compared to the control recorded $(1.73 \mathrm{mg} / \mathrm{g}$ meat). Meat substituted with a concentration of $40 \%$ of truffles and preserved in freezing recorded significant $(p<0.05)$ superiority in reducing the concentration's cholesterol concentration by $30 \%$. These results are satisfactory, as the reason for low cholesterol can be attributed to the fact that many antioxidant compounds contain phenolic compounds such as ascorbic acid, which have the property to scavenge free radicals from oils when applied to food (Hamza et al 2016) and thus provide protection.

Table 3 The effect of partial substitution of quantities on the concentration of beef tablets.

\begin{tabular}{|c|c|c|c|c|c|}
\hline \multirow[t]{2}{*}{ Concentration (\%) } & \multirow[b]{2}{*}{0} & \multicolumn{2}{|c|}{ Periods (day) } & \multirow[b]{2}{*}{60} & \multirow[t]{2}{*}{ Mean (ml) } \\
\hline & & 15 & 30 & & \\
\hline 0 & 1.47 & 1.73 & 1.73 & 1.73 & 1.67 \\
\hline 20 & 1.47 & 1.63 & 1.61 & 1.61 & 1.58 \\
\hline 40 & 1.47 & 1.53 & 1.31 & 1.48 & 1.45 \\
\hline 60 & 1.47 & 1.56 & 1.42 & 1.06 & 1.38 \\
\hline Mean & 1.47 & 1.61 & 1.52 & 1.47 & \\
\hline \multicolumn{5}{|c|}{0.267} & RLSD \\
\hline \multicolumn{5}{|c|}{0.131} & SEM interaction \\
\hline
\end{tabular}

\section{Microbial traits}

\section{The total count of bacteria}

It is noticed from Table 4 that there is a significant decrease $(p<0.05)$ in the total count of bacteria when treating fever tablets made from quanta with different concentrations compared to the control treatment in which the average number of bacteria was $292.33 \times 10^{4} \mathrm{cfu} / \mathrm{g}$ at the second month. 
The partial replacement of meat with quanta at $20 \%$ concentrations was superior in reducing the total count of bacteria to $(41.67,59.00,67.67) 10^{4} \mathrm{cfu} / \mathrm{g}$, while the second treatment at $40 \%$ concentrations reached the average number. To $(40.00,42.33$, and 58.67$) 10^{4} \mathrm{cuf} / \mathrm{g}$, as for the concentration of $60 \%$, the total count number of bacteria decreased to $\left(46.33,45.67\right.$, and 69.67) $10^{4} \mathrm{cuf} / \mathrm{g}$ during the freezing periods of 15,30 , and 60 days of the storage period, respectively. The reason for the decrease in the total number of bacteria in the meat for treating with cama is due to its containment of active compounds such as flavonoids, resins, and soaps (Janakat 2004; Janakat et al 2005). Also, it can be noted from the results of Table 3 a significant decrease in the total number of bacteria in meat samples. The substitution in quanta at concentrations of $20 \%$ for all preservation periods compared to processed meat samples from Alkma for different concentrations. This result is encouraging for the use of quanta in the manufacture of minced meat tablets.

Table 4 The effect of partial substitution of quantities on the total count bacteria for beef discs $\left(\times 10^{4} \mathrm{cfu} / \mathrm{g}\right)$.

\begin{tabular}{|c|c|c|c|c|c|}
\hline \multirow[t]{2}{*}{ Concentration (\%) } & \multirow[b]{2}{*}{0} & \multicolumn{2}{|c|}{ Periods (day) } & \multirow[b]{2}{*}{60} & \multirow[t]{2}{*}{ Mean (ml) } \\
\hline & & 15 & 30 & & \\
\hline 0 & 36.00 & 156.67 & 279.33 & 292.33 & 191.08 \\
\hline 30 & 36.00 & 41.67 & 59.00 & 67.67 & 51.08 \\
\hline 40 & 36.00 & 40.00 & 42.33 & 58.67 & 44.25 \\
\hline 60 & 36.00 & 46.33 & 45.67 & 69.67 & 49.42 \\
\hline Mean & 36.00 & 71.17 & 106.58 & 0122.08 & \\
\hline \multicolumn{5}{|c|}{5.506} & RLSD \\
\hline \multicolumn{5}{|c|}{2.703} & SEM interaction \\
\hline
\end{tabular}

The numbers of cryophilic bacteria

Table 5 shows a significant decrease $(p<0.05)$ for the numbers of cold-loving bacteria and for all treatments replaced with meat tablets compared to the first treatment (control), whose average number of cold-loving bacteria reached $93.00 \times 10^{4} \mathrm{cfu} / \mathrm{g}$ as for the added meat treatments. It also reduced the number of bacteria to $59.00,55.6$, and $60.3310^{4} \mathrm{cfu} / \mathrm{g}$ at the end of the second month of freezing preservation, respectively.

The concentration of $40 \%$ of the substituted beef was higher in reducing the number of cold-loving bacteria to $40.58 \mathrm{cfu} / \mathrm{g}$, followed by the significant effect of $60 \%$, with an average number of the reason is that the plants contain active compounds such as alkaloids, phenols, glycosides, and resins. This result is consistent with (Janakat et al 2004). It was found that the numbers of total cold-loving bacteria decreased in beef tablets that were added to the quantities and stored by freezing for a period of 4 months.

\begin{tabular}{|c|c|c|c|c|c|}
\hline \multirow[t]{2}{*}{ Concentration (\%) } & \multirow[b]{2}{*}{0} & \multicolumn{2}{|c|}{ Periods (day) } & \multirow[b]{2}{*}{60} & \multirow[t]{2}{*}{ Mean (ml) } \\
\hline & & 15 & 30 & & \\
\hline 0 & 22.00 & 74.33 & 86.33 & 93.00 & 69.42 \\
\hline 20 & 22.00 & 48.33 & 53.00 & 54.00 & 45.58 \\
\hline 40 & 22.00 & 32.33 & 52.33 & 55.67 & 40.58 \\
\hline 60 & 22.00 & 40.33 & 54.00 & 60.33 & 44.17 \\
\hline Mean & 22.00 & 48.83 & 61.92 & 67.00 & \\
\hline \multicolumn{5}{|c|}{0.05064} & RLSD \\
\hline \multicolumn{5}{|c|}{0.02486} & SEM interaction \\
\hline
\end{tabular}

\section{Conclusions}

The results showed that the addition of plant truffles led to a decrease in oxidation indicators through the peroxide number in the treated meat preserved by the cold. A significant decrease in the percentage of free fatty acids in the meat samples that were treated with truffles compared to the control treatment. A significant decrease in the cholesterol concentration in the meat samples that was added to it when it did not show a significant effect on the cholesterol concentration of beef compared to the control treatment.

On the other hand, the results showed that the use of truffles led to a reduction in the increase in microbial contamination of chilled meat through a decrease in the numbers of total and cold-loving bacteria compared to the control treatment. The use of truffles in the manufacture of beef led to a prolonged preservation period of ten days.

\section{Conflict of Interest}


The authors declare no conflict of interests.

\section{References}

Abd al-Hamid TM (1990) The Science of Meat, first edition. Ministry of Higher Education and Scientific Research, University of Basra, Iraq.

Akyuz M (2013) Nutritive value, flavonoid content and radical savenging activity of the truffle (Terfeziaboudieri Chatin). J Soil Sci Plant Nutr 13:143-151.

Al-Abidi FAM (1999) Evaluation of the Qualitative and Chemical Characteristics of the Japanese Goosebird Egg (Coturnix coturnix japonica). PhD Thesis, Faculty of Agriculture, University of Baghdad.

Al-Aswad MB, Al Douri LD (2001) Sensory Characteristics ofBarker Meat Partially Substituted by Vegetable Alternatives. Basra Journal of Agricultural Sciences 4.

Aldebasi YH, Aly SM, Qureshi MA, Khadri H (2013) Novel antibacterial activity of Terfiziaclaveryi aqueous extract against clinical isolates of corneal ulcer. Afr J Biotechnol 12:6340-6346.

Al-Hamili S, Khalaf M (2005) Substituting beef with aged chicken meat and soy protein in beef baker production. Master Dissertation, College of Education, University of Basra.

Al-Laith AAA (2010) Antioxidant components and antioxidant/antiradical activities of desert truffle (Tirmanianivea) from various Middle Eastern origins. J Food Compos Anal 23:15-22.

Al-Salhi KJC (2012) The effect of injection of Japanese quail eggs (Cotwnix Japonica) with the hormones testosterone, estrogen and vitamin $\mathrm{C}$ on some reproductive, physiological, behavioral and productive characteristics. PhD thesis, College of Agriculture, University of Basra, Iraq.

Chye FY, Wong YJ, Lee J (2008) Nutritional quality and antioxidant activity of selected edible wild mushrooms. Food Sci Tech Int 14:375-384.

Dunkwal V, Jood S, Singh S (2007) Physico-chemical properties and sensory evaluation of Pleurotus sajor caju powder as influenced by pre-treatments and drying methods. British Food Journal 109:749-759.

Ferreira ICFR, Barros L, Abreu MRV (2009) Antioxidants in wild mushroom. Cur Med Chem 16:1543-1560.

Gutièrrez A, Morte A, Honrubia M (2003) Morphological characterization of mycorrhizae formed by Helianthemum with Terfezia claveryi Chatin and Picoalefebvrei (Pat.) Maire. Mycorrhiza 13:299-307.

Hamza A, Zouari N, Zouari S, Jdir H, Zaidi S, Gtari M, Neffati M (2016) Nutraceuticalpotential, antioxidant and antibacterial activities of Terfezia boudieri Chatin, a wild edible desert truffle from Tunisia arid zone. Arab J Chem 9:383-389.

Heleno SA, Barros L, Sousa MG, Martins A, Ferreira ICFR (2010) Tocopherols composition of Portuguese wild mushrooms with antioxidant capacity. Food Chem 119:1443-1450.

Janakat S, Al-Fakhiri S, Sallal AK (2004) A promising peptide antibiotic from Terfezia claveryi aqueous extract against Staphylococcus aureus in vitro. Phytotherapy Research 18:810-813.

Janakat S, Al-Fakhiri S, Sallal AK (2004) A promosing peptide antibiotic from Terfeziaclaveryi aqueous extract against Staphylococcus aureus in vitro. Phytother Res 18:810-813.

Janakat SM, Al-Fakhiri SM, Sallal AK (2005) Evaluation of antibacterial activity of aqueous and methanolic extracts of the truffle TerfeziaclaveryiagainstPseudomonaseruginosa. Saudi Med J 26: 952-955.

Khan MA, Hassan L, Ahmad SD, Shah AH, Batool F (2009) In vitro regeneration potentiality of oil seed Brassica genotypes with differential BAP concentration. Pak J Bot 41:1233-1239.

Kotwaliwale N, Bakane P, Verma A (2007) Changes in textural and optical properties of oyster mushroom during hot airdrying. Journal of Food Engineering 78:1207-1211.

Morte A, Honrubia M, Gutiérrez A (2008) Biotechnology and Cultivation of Desert Truffles. Mycorrhiza: pp. 467-483.

Pearson D, Egan H, Kirk RS, Sawyer R (1981) Chemical analysis of food.Longman Scientific and Technical New York.

Pereira E, Barros L, Martins A, Ferreira ICFR (2012) Towards chemical and nutritional inventory of portuguese wild edible mushrooms in different habitats. Food Chem 130:394-403.

SPSS (2006) Statistical Packages of Social Sciences. Version 15 for windows. SPSS. Inc. USA. 